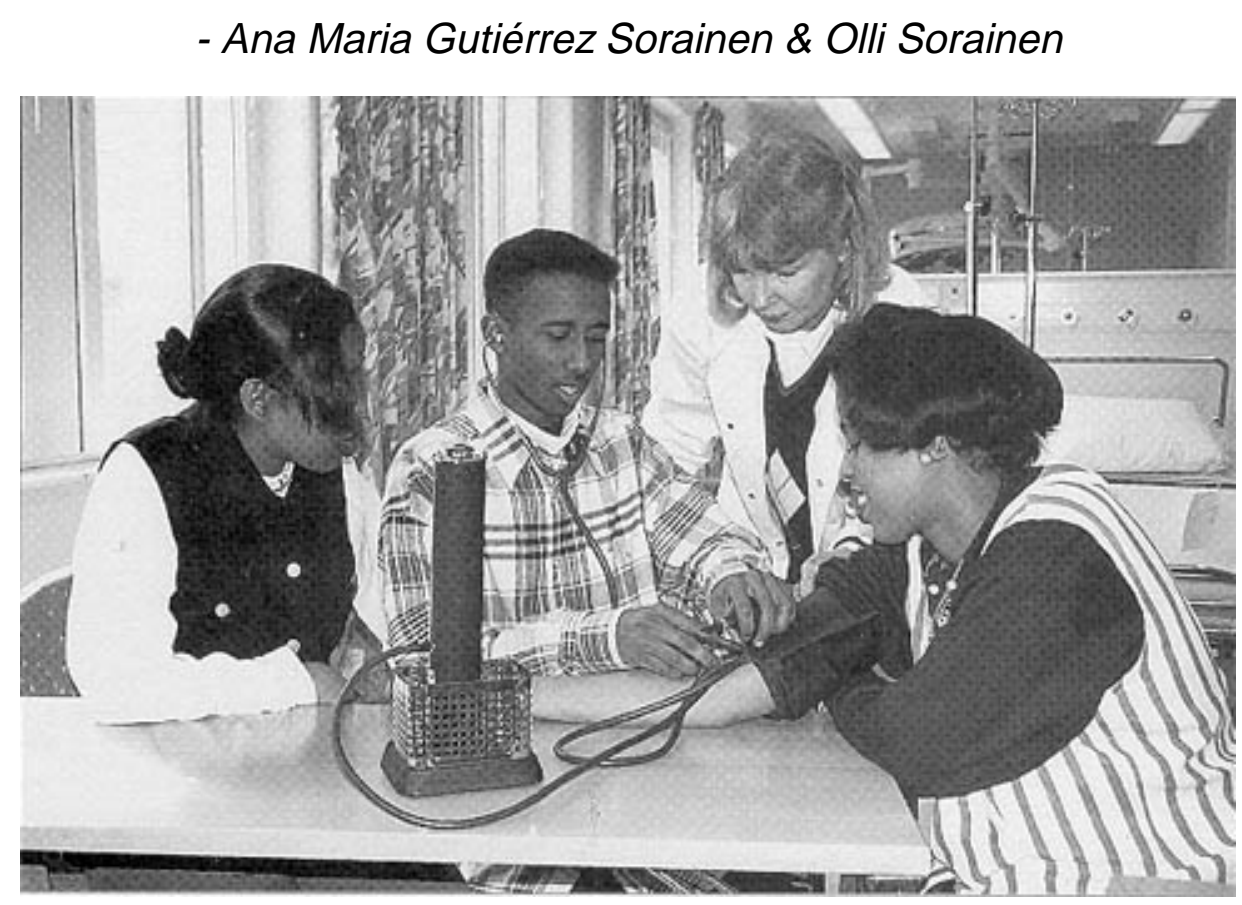

Helsingin Diakoniaopisto järjestää maahanmuuttajien koulutusta. Kuvassa opiston lähihoitajaryhmän opiskelijoita, jotka suorittavat suomalaista sosiaali- ja terveysalan perustutkintoa.

\title{
Maahanmuuttokoulutus Suomessa
}

UIkomaalaisten laajempi muutto Suomeen alkoi myöhään verrattuna muihin Pohjoismaihin ja Euroopan maihin. Suomeen ensimmäinen merkittävä vieraskulttuuria edustava ryhmä tuli 1973 Chilestä ja seuraava 1979 Vietnamista. Vasta 1980-luvun alussa Suomi alkoi muuttua maaksi, johon muutetaan. Aikaisemmin Suomesta oli etupäässä lähdetty.

Suomeen saapuvat ulkomaalaiset edustavat monenlaisia ryhmiä, kuten paluumuuttajia, turvapaikanhakijoita, pakolaisia ja muita maahanmuuttajia. Seuraavassa käsittelemme Suomeen enemmän tai vähemmän pysyvästi asettuvia aikuisia ulkomaalaisia (ryhmä "muut maahanmuuttajat").

Myöhäisen saapumisen takia maahanmuuttajien integroinnista suomalaiseen yhteiskuntaelämään ei ole voitu selvitä yhtä helpolla kuin muualla Euroopassa eli harjaannuttamalla maahanmuuttajia pääasiassa teollisuuden vaihetuotantotehtäviin. Suomessa ne työt, jotka muissa Euroopan maissa muodostavat perinteiset vierastyömarkkinat (ris. alempiarvoiset työt) olivat Suomessa maahanmuuttajien saapuessa jo täynnä. Tämä johtui suomalaisten naisten laajasta osallistumisesta palkkatyöhön. (Esim. Paananen 1993, 11.) Maahanmuuttajien sopeuttamisessa työmarkkinoille oli Suomessa siis alusta lähtien tähdättävä monipuolisen ammattitaidon hankkimiseen.

Suomessa, kuten muissakin Pohjoismaissa maahanmuuttajien ammattitaidon hankinta alkaa työhön ja koulutukseen valmentavalla kurssituksella eli maahanmuuttokoulutuksella. Siinä pyritään eräänlaisen pikaisen uudelleensosialisaation kautta integroimaan muualta tullut suomalaiseen yhteiskuntaan. Muutaman kuukauden kurssilla maahanmuuttajalle tarjotaan tilaisuus oppia yhteiskuntataidot, jotka suomalainen hankkii vuosien ja vuosikymmenten aikana.

Suomessa pisimmät perinteet on pakolaisten ohjaavalla koulutuksella. Se käynnistyi 1979 Pääkaupunkiseudun ammatillisessa kurssikeskuksessa Kaakkois-Aasian pakolaisten ammatillisella 
esikurssilla. Muiden maahanmuuttajien työelämään ja koulutukseen valmentava koulutus alkoi 1985. (Opetushallitus 1993, 3.) Laajamittaisen maahanmuuton alkamisesta ehti Suomessa siis kulua 12 vuotta ennen kuin jossain määrin kattava yhteiskuntaan sopeuttava koulutus saatiin alkuun.

\section{Maahanmuuttopolitiikka ja koulutuspolitiikka Pohjoismaissa ja Suomessa}

Minna Domanderin siirtolaistutkimuksen mukaan Tanskan, Ruotsin ja Norjan maahanmuuttopolitiikat ovat kehittyneet Suomeen verrattuna hyvin varhain ja keskenään samantapaisesti. Tanskassa ja Norjassa työnantajat ehdottivat 1960-luvun taloudellisen kasvun kaudella, että maahan tuotettaisiin siirtolaistyövoimaa. Ulkomaisen työvoiman tarpeen ja sen tyydyttämisen pohjalta näissä maissa laadittiin yhtenäiset ulkomaalaispolitiikat lainsäädännön tasolla jo 1960-70 -lukujen vaihteessa.

Ruotsin maahanmuuttopolitiikka muotoutui ennen kaikkea suomalaisten laajan maahanmuuton vaikutuksesta 1960-70 -luvulla. Pohjoismaisen yhteistyön vuoksi suomalaiset olivat tasa-arvoisia ruotsalaisten kanssa asuntoja työmarkkinoilla. Niinpä Pohjoismaiden ulkopuolelta muuttavilta oli vaikea evätä näitä oikeuksia. Ruotsi saavutti jo varhaisessa vaiheessa yhdenvertaisuuden maahanmuuttopolitiikassaan.

Suomen maahanmuuttopolitiikan tavoitteet ovat alkaneet selkeytyä vasta viime aikoina. Suomalaisen maahanmuuttopolitiikan strategia perustuu Domanderin mukaan ensiksi omien työvoimavarojen täysimittaiseen käyttöön, ennen kuin ulkomailta ryhdytään rekrytoimaan työvoimaa.

Erilaiset maahanmuuttostrategiat näkyvät eri Pohjoismaiden ulkomaalaisväestön määrässä. Ulkomaalaisten osuus väestöstä oli vuonna 1988 Ruotsissa 5, Norjassa 3,2Janskassa 2,9 ja Suomessa 0,4 prosenttia. Luvut perustuvat Pohjoismaiden Ministerineuvoston julkaisuun Yearbook of Nordic Statistics 1989/90.

Suomessa maahanmuuttajien koulutuspoliittiset linjaukset saatiin hahmoteltua vasta 1992, jolloin opetushallitus julkaisi koulutuspoliittisen kannanoton kieli- ja kulttuurivähemmistöjen koulutuksesta. Nyt laajamittaisen maahanmuuton alkamisesta oli Suomessa ehtinyt kulua 19 vuotta.

Yksi koulutuspoliittisen kannanoton tärkeä periaate on, että kaikille maahanmuuttajille annetaan yhtäläiset mahdollisuudet koulutukseen maahanmuuton syystä riippumatta. Samoin pidetään tärkeänä maahanmuuttajan mahdollisuutta täydentää koulutustaan ja ammattitaitoaan suomalaiseen yhteiskuntaan soveltuvaksi. (Opetushallitus 1993, 4). Kannanotossa korostetaan siis sekä koulutuksellista tasa-arvoa että yksilöllistä näkökulmaa.

\section{Maahanmuuttokoulutuksen ongelmia: Suomen työmarkkinat}

Maahanmuuttokoulutuksen tehtävä on hankala. Suomessa opetushallituksen koulutuspoliittisen kannanoton mukaan maahanmuuttajalle pitäisi tarjota koulutusta, myös maahanmuuttokoulutusta yksilön tarpeista lähtien ja yksilön ainutlaatuinen elämänkokemus huomioon ottaen. Samanaikaisesti pitäisi kuitenkin lähteä myös yhteiskunnan (lue: työmarkkinoiden) tarpeesta. Yksilön ja yhteiskunnan koulutustarpeet voivat olla jyrkässä ristiriidassa.

Suomessa, kuten muissakin länsimaissa toivotaan ja halutaan uskoa nykyisin, että koulutettujen ja ammattitaitoisten ihmisten siirtolaisuus on hallitseva kansainvälisen liikkumisen muoto. Kansainvälisen kilpailukyvyn katsotaan syntyvän osaavien ihmisten, modernin tuotantolaitteiston ja tehokkaan organisaation tuloksena. Kansantalouksien suhteelliseen kilpailukykyyn vaikuttavat raaka-aineiden sijaan entistä enemmän osaavat ihmiset. (Paananen 1993, 23.). Kuitenkin Euroopassa yhä pienempi osuus siirtolaisuudesta on Euroopan sisäistä ja yhä suurempi osa tulee kehitysmaista (Domander 1992, 9). 
Domanderin mukaan Suomessa maahanmuuttokursseille on yleensä ollut huomattavasti enemmän tulijoita kuin on tarjontaa. Kuka sitten kursseille on päässyt?

Pohjakoulutus on ollut merkittävänä kriteerinä esimerkiksi Tampereen ammatillisen aikuiskoulutuskeskuksen työvoimapoliittisessa maahanmuuttokoulutuksessa. Käytännössä on vaadittu sellaista ammatillista pohjakoulutusta tai korkeakoulutaustaa, jolla on Pirkanmaan työmarkkinoiden kannalta jotain merkitystä. Eniten maahanmuuttokoulutukseen on Tampereella päässyt eurooppalaisia. Euroopassa väestö on keskimäärin koulutetumpaa kuin muissa maanosissa ja ammatilliset kvalifikaatiot ovat lähellä pirkanmaalaisia vaatimuksia.

Työmarkkinoiden tarpeen painottuminen selittyy sillä, että Suomessa työhallinto ostaa maahanmuuttokoulutuksen tarjouskilpailun perusteella ammatillisilta aikuiskoulutuskeskuksilta. Osallistujat maahanmuuttokoulutukseen valitsee paikallinen työvoimatoimisto.

Ruotsissa maahanmuuttokoulutus ei ole yhtä suoranaisesti tekemisissä työmarkkinoiden vaatimusten kanssa kuin Suomessa. Maahanmuuttokoulutuksen järjestävät kunnat ja kaikilla pysyvästi maahan asettuvilla on oikeus osallistua koulutukseen.

Monista muista Euroopan maista poiketen vierastyöläiset eivät perinteisesti ole olleet elintärkeitä Suomen työmarkkinoilla, mikä on näkynyt yhtenäisen maahanmuuttajien koulutuspolitiikan viivästymisessä. Kun maahanmuuttokoulutukseen pääsemisestä päättää paikallinen työvoimatoimisto, koulutukseen pääsemiseen vaikuttaa hyvin pitkälle yhteiskunnan eli paikallisten työmarkkinoiden tarve.

Suurtyöttömyys vähentää siirtotyöläisten tarvetta - ja myös koulutustarvetta - Suomessa entisestään. Vientipainotteinen ja julkista sektoria purkava taloudellinen strategia puolestaan aiheuttaa yhä enemmän erilaisuutta paikallisten työmarkkinoiden ja niiden tarpeiden välillä.

\section{Maahanmuuttokoulutuksen sisältö}

Maahanmuuttajien yhtenäisen koulutuspolitiikan puuttuminen on myös hidastanut kuitenkin laadullista ja määrällistä kehittämistä. Opetuksen sisältö on käytännössä jäänyt suurelta osin opetusta järjestävien organisaatioiden vastuulle. Tällöin koulutuksen toteutus ja opetuksen sisältö ovat myös pitkälle määräytyneet paikallisten työmarkkinoiden tarpeen mukaisesti.

Uusi opetussuunnitelmasuositus puhuu noin 40 viikon mittaisesta kolmeen osaan jakautuvasta opintokokonaisuudesta. Kielenopetus tähtää sellaisen tiedon ja taidon antamiseen suomen tai ruotsin kielestä, että henkilö pystyy valvomaan oikeuksiaan, vaikuttamaan elämäntilanteeseensa ja täyttämään jokapäiväisen elämän velvollisuudet. Kielen opintokokonaisuutta täydentävät yhteiskunta- ja kulttuuritietouden sekä ohjauksen opintokokonaisuudet. (Opetushallitus 1993, i.)

Jokaiselle opiskelijalle laaditaan henkilökohtainen opintosuunnitelma. Opetushallituksen laatimissa maahanmuuttokoulutuksen opetussuunnitelman perusteissa (1992, 10-11) korostetaan opiskelijan subjektiutta oman elämänsä suhteen, koska monissa niistä koulutusjärjestelmistä, joista maahanmuuttajilla on kokemuksia, oppimisen tavoitteet, menetelmät ja oppimistulosten arviointi on määritelty opiskelijan ulkopuolelta.

Maahanmuuttokoulutuksen sisältöä siis ainakin yritetään muokata myös opiskelijoiden henkilökohtaisten tilanteiden pohjalta. Maahanmuuttajien koulutuspoliittinen kannanotto korostaakin juuri yksilöllistä näkökulmaa ja yksilön koulutustarvetta (Opetushallitus 1993, 4). 


\section{Maahanmuuttokoulutuksen ongelmia: maahanmuuttajat}

Maahanmuuttokoulutukseen osallistuvien eri kielet, kulttuurit ja elämänhistoriat tarjoavat henkilökohtaisia opetussuunnitelmia laativalle pähkinän purtavaksi. Ohjaavan koulutuksen psykologi Riitta Metsänen Tampereen ammatillisesta aikuiskoulutuskeskuksesta totesi kirjoittajien tekemässä haastattelussa marraskuussa 1993 erilaisiin elämäntilanteisiin ja oppimistarpeisiin paneutumisen sekä niiden sovittamisen kurssin resursseihin ja yhteiskunnan realiteetteihin käyvän usein yli yhden opettajan voimien.

Samalla kurssilla voi olla käytännössä luku- ja kirjoitustaidottomia sekä korkean koulutuksen saaneita, esimerkiksi koulua käymätön kalastaja ja yliopistollisen koulutuksen saanut lääkäri- Samalle kurssille voi myös osua keskenään vihaa pitävien etnisten ja uskonnollisten ryhmien edustajia, kuten turkkilaisia ja kurdeja tai arabeja ja juutalaisia.

Opiskelua saattaa yllättäen haitata myös monella maahanmuuttajalla rahan puute. Hannele Pylväinen toteaa raportissaan Pakolaiset Suomen työelämässä, että vaikka koulutuksen aikainen toimeentulo olisikin järjestetty, opiskelija näkee usein oikeaksi lähettää rahat kotimaassa olevalle perheelleen silläkin uhalla, että itse näkisi nälkää.

Lisämutkia tuottaa vielä se, että maahanmuuttajan elämänvaihe tai sukupolvi ei aina löydä paikkaansa ikäisensä kantaväestön joukossa. jos sukupolvi määritellään sen jäsenten jakamien yhteisten elämänkokemusten kautta, Suomeen muuttava nuori nicaragualainen kuuluisi Suomen sodat ja puutteen kokeneeseen iäkkääseen sukupolveen.

Näiden suomalaisten sukupolvien eikä usein maahanmuuttajienkaan kokemukseen ei ole kuulunut koulutus kovin laajasti. Kehitysmaasta tullut maahanmuuttaja ei useinkaan ole sisäistänyt eurooppalaista elinikäisen koulutuksen mallia. Maahanmuuttokoulutuksen jälkeen hän ei aina ole halukas hakeutumaan ammatilliseen tai täydentävään koulutukseen (esim. Pylvänäinen 1989, 49).

Maahanmuuttajan yksilöllisen koulutustarpeen toteutuminen on siis käytännön syistäkin hankalaa. Suomen maahanmuuttokoulutusperinteen lyhyys ja sirpaleisuus kuitenkin usein aiheuttaa sen, että käytännön hankaluuksista tulee helposti ylitsepääsemättömiä ongelmia.

\section{Lopuksi}

Eri kulttuurista tuleville tietojen saaminen uudesta yhteiskunnasta on tärkeää, jotta selvitään päivittäisistä askareista ja yhteydenpidosta kantaväestöön. Aikuisten maahanmuuttajien pitkää ja mutkikasta integraatioprosessia helpotetaan juuri maahanmuuttokoulutuksella.

Suomessa naisten laajan palkkatyöhön osallistumisen takia työmarkkinoilla ei ole tarvittu siirtotyövoimaa, joten ulkomaalaisten määrä on pysynyt pienenä ja näin ulkomaalaispolitiikan tarvekaan ei ole ollut suuri. Suomessa maahanmuuttajien yhtenäisen koulutuspolitiikan viivästyminen on kuitenkin saanut aikaan sen, että hallitseva maahanmuuttokoulutukseen pääsyn kriteeri on ollut työmarkkinoiden tarve.

Tämä Suomen työmarkkinoiden erityispiirre yhdessä maahanmuuttokoulutuksen käytännön ongelmien kanssa on hankaloittanut vuoden 1992 mahanmuuttajien koulutuspoliittisen kannanoton tavoittelemien periaatteiden (koulutuksellinen tasa-arvo ja yksilöllinen näkökulma) toteuttamista.

Väestönkasvu, maailman kriisipesäkkeet sekä talouden ja kulttuurien kansainvälistyminen pitänevät huolta siitä, että Suomessa on lähitulevaisuudessa varauduttava yhä lisääntyvään ulkomaalaisten maahanmuuttoon. Yhä pienempi osa maahanmuuttajista on hyvin koulutettuja eurooppalaisia, joilla on Suomen työmarkkinoille kitkatta sopiva ammattitaito. 
Maahanmuuttajan kokemalle koulutustarpeelle on tulevaisuudessa pantava enemmän painoa. Tämä merkitsee automaattisesti myös koulutusorganisaatioissa toimivan opettajakunnan täydennyskoulutustarvetta.

\section{LÄHTEET JA KIRJALLISUUITA}

Domander Minna 1992.- Maahanmuuttajat ja koulutus. Siirtolaisuustutkimuksia, A 16. Siirtolaisuusinstituutti, Turku.

Opetushallitus 1993: Maahanmuuttajien ammatillinen koulutus. Suositus opetussuunnitelmien perusteeksi. Opetushallituksen julkaisusarjat, Opetussuunnitelmasarja, 14. Helsinki.

Opetushallitus 1992: Maahanmuuttokoulutus - opetussuunnitelman perusteet. Luonnos 20.5. Helsinki.

Paananen, Seppo 1993: Työvoimaa rajan takaa. Työministeriö, työvoimapoliittisia tutkimuksia, 54. Helsinki.

Pylvänäinen, Hannele 1989.-Pakolaiset Suomen työelämässä.

Suomeen vuosina 1979-86saapuneiden Kaakkois-Aasian pakolaisten sijoittuminen työmarkkinoille. Sosiaalihallitus, raporttisarja, 17. Helsinki.

Tuomaria, Irmeli 1993: Tosiasioita pakolaisista ja turvapaikanhakijoista, 2. Sosiaali- ja terveysministeriö, Pakolaistoimisto. Helsinki. 